\title{
Resistance to Three Distinct Begomovirus Species in the Agronomical Superior Tropical Pumpkin Line AVPU1426 Developed at the World Vegetable Center
}

\author{
Narinder P. S. Dhillon ${ }^{1, *}$, Supornpun Srimat ${ }^{1}$, Suwannee Laenoi ${ }^{1}$, Anjana Bhunchoth ${ }^{2}$, Bencharong Phuangrat ${ }^{2}$, \\ Nuchnard Warin ${ }^{2}$, Rungnapa Deeto ${ }^{2}$, Orawan Chatchawankanphanich ${ }^{2}$, Kriskamol Na Jom ${ }^{3}$, Sudathip Sae-tan ${ }^{3}$, \\ Suk-Woo Jang ${ }^{4}$, Hyungjun Noh ${ }^{5}$, Roland Schafleitner ${ }^{6}\left(\mathbb{D}\right.$, Yuan-Li Chan ${ }^{7}$ (D), Belén Picó ${ }^{8}$, Cristina Sáez ${ }^{8}$ (D) \\ and Lawrence Kenyon ${ }^{7}$ (D)
}

check for updates

Citation: Dhillon, N.P.S.; Srimat, S.; Laenoi, S.; Bhunchoth, A.; Phuangrat, B.; Warin, N.; Deeto, R.; Chatchawankanphanich, O.; Jom, K.N.; Sae-tan, S.; et al. Resistance to Three Distinct Begomovirus Species in the Agronomical Superior Tropical Pumpkin Line AVPU1426 Developed at the World Vegetable Center. Agronomy 2021, 11, 1256. https:// doi.org/10.3390/agronomy11061256

Academic Editor: Tristan Edward Coram

Received: 24 May 2021

Accepted: 17 June 2021

Published: 21 June 2021

Publisher's Note: MDPI stays neutral with regard to jurisdictional claims in published maps and institutional affiliations.

Copyright: (c) 2021 by the authors. Licensee MDPI, Basel, Switzerland. This article is an open access article distributed under the terms and conditions of the Creative Commons Attribution (CC BY) license (https:/ / creativecommons.org/licenses/by/ $4.0 /)$.
1 World Vegetable Center, East and Southeast Asia, Kasetsart University, Kamphaeng Saen 73140, Thailand; supornpun.srimat@worldveg.org (S.S.); suwannee.laenoi@worldveg.org (S.L.)

2 National Center for Genetic Engineering and Biotechnology (BIOTEC), National Science and Technology Development Agency (NSTDA), Khlong Luang 12120, Thailand; anjana@biotec.or.th (A.B.); bencharong.phua@biotec.or.th (B.P.); wnuch@biotec.or.th (N.W.); rungnapa.dee@biotec.or.th (R.D.); orawan@biotech.or.th (O.C.)

3 Department of Food Science and Technology, Faculty of Agro-Industry, Kasetsart University, Bangkok 10900, Thailand; kriskamol.n@ku.ac.th (K.N.J.); huikengv@gmail.com (S.S.-t.)

4 National Institute of Horticultural \& Herbal Science, Rural Development Administration, 370, Nongsaengmyeong-ro, Deockjin-gu, Jeonju-si 54874, Korea; swjang02@korea.kr

5 National Agrobiodiversity Center, National Institute of Agricultural Sciences, Rural Development Administration, 370, Nongsaengmyeong-ro, Deockjin-gu, Jeonju-si 54874, Korea; jumpspace@korea.kr

6 Biotechnology, World Vegetable Center, 60 Yi-Min Liao, Shanhua, Tainan 74151, Taiwan; roland.schafleitner@worldveg.org

7 Virology, World Vegetable Center, 60 Yi-Min Liao, Shanhua, Tainan 74151, Taiwan; yuan-li.chan@worldveg.org (Y.-L.C.); lawrence.kenyon@worldveg.org (L.K.)

8 Instituto Universitario de Conservación y Mejora de la Agrodiversidad Valenciana, Universitat Politècnica de València (COMAV-UPV), 46022 València, Spain; mpicosi@btc.upv.es (B.P.); crisaesa@upvnet.upv.es (C.S.)

* Correspondence: narinder.dhillon@worldveg.org

Abstract: The Squash Leaf Curl China Virus (SLCCNV) and Tomato Leaf Curl New Delhi Virus (ToLCNDV) are species of Begomovirus (whitefly-vectored Geminiviridae) and cause serious damage to the cucurbit crops of the genus Cucurbita in the areas of South and Southeast Asia, across Asia, the Middle East and the Mediterranean, respectively. Cucurbita moschata's inbred line AVPU1426, developed at the World Vegetable Center (WorldVeg) from a Bangladeshi landrace through pedigree selection, was observed to be resistant to both begomoviruses in field tests conducted at the WorldVeg Research and Training Station, Kasetsart University, Kamphaeng Saen, Thailand, which is a hotspot for these viruses. When AVPU1426 was tested for reaction to inoculation by viruliferous whiteflies with Squash Leaf Curl Philippines Virus (Taiwan strain) (SLCPV-TW) in the screen net-house at WorldVeg headquarters in Taiwan, it showed good resistance, though SLCPV-TW DNA-A could be detected in all inoculated plants, indicating that it did not show immunity to this virus. The objective of this study was to validate the resistance to SLCCNV and ToLCNDV in AVPU1426 by using whitefly-mediated inoculations to determine the mode of inheritance of the resistance. The results showed that AVPU1426 was resistant to SLCCNV and ToLCNDV. Upon crossing AVPU1426 with a susceptible check variety, Waltham Butternut, the resistance to both begomoviruses was observed to be conferred by a single recessive gene. This open-pollinated pumpkin line AVPU1426 bears flat round, mottled green immature fruits with yellow flesh in mature fruit. The fruit yield of AVPU1426 (20.74 t/ ha $\left.{ }^{-1}\right)$ was comparable to 'Rajah' (18.61 t/ ha $\left.{ }^{-1}\right)$, a recently released commercial F1 hybrid of East-West Seed (EWS). The fruit of AVPU1426 were estimated to have a good average $\beta$-carotene content $(1.57 \mathrm{mg} / 100 \mathrm{~g}$ fresh weight). This line is a good source to breed pumpkins resistant to the three begomoviruses. 
Keywords: Cucurbita moschata; Begomovirus; SLCCNV; SLCPV-TW; ToLCNDV; virus resistance; Bemisia tabaci; quality traits

\section{Introduction}

Tropical pumpkin, Cucurbita moschata Duchesne, is a highly nutritious cucurbitaceous crop of American origin that is widely cultivated in home gardens and by small-scale producers in some areas of Africa and Asia but has huge potential for expansion and income generation. Pumpkin fruits are rich sources of alpha- and beta-carotenes and other carotenoids [1]. The world production of squash, pumpkins, and gourds in 2019 was estimated at 22.9 million $t$ from 1.53 million ha [2]. Productivity of these cucurbits is high in North America (24.09 t/ha ${ }^{-1}$ ) compared to Asia $\left(13.12 \mathrm{t} / \mathrm{ha}^{-1}\right)$ and Africa $\left(7.84 \mathrm{t} / \mathrm{ha}^{-1}\right)$. Begomoviruses such as Squash Leaf Curl China Virus (SLCCNV) and Tomato Leaf Curl New Delhi Virus (ToLCNDV), are diseases of significant importance to cucurbitaceous crops in the tropics and subtropics of Asia, Northern Africa and Southern Europe and can cause yield losses of up to $100 \%[3,4]$. Both of these viruses are transmitted by some whiteflies of the Bemisia tabaci cryptic species complex in a persistent, circulative, but non-propagative manner [5] and the characteristic symptoms in cucurbits are chlorotic foliar mosaic and mottling accompanied by leaf curling and stunted plant growth.

The European and Mediterranean Plant Protection Organization (EPPO) added ToLCNDV to their alert list in 2015 [6], whereas SLCCNV has not yet been classified as a quarantine pest by any plant protection organization. Most methods to control these two viruses in cucurbits rely on vector management by the use of insecticides and creating physical barriers in greenhouses or net-houses. In addition, good agricultural practices such as removal (roguing) of virus-infected plants and weeds and releasing of whitefly natural enemies are advocated [7], though the deployment of resistant cultivars is the most environmentally friendly and sustainable approach to controlling the production losses caused by these begomoviruses. However, searching for sources of resistance and transferring resistance gene(s) into commercial cultivars is a major undertaking. SLCCNV and ToLCNDV are present at high incidences during February-April every year in the pumpkin fields at the World Vegetable Center (WorldVeg), Research and Training Station in the Kasetsart University campus, Kamphaeng Saen, Thailand. Pumpkin plants of the susceptible check variety exhibit $100 \%$ susceptibility if grown in the field during this period.

A field screening of 800 accessions of $C$. moschata against ToLCNDV and SLCCNV revealed segregation for virus resistance and other fruit traits such as skin color (mottled green, black-green, light green), shape (flat round, oval, round, long), and flesh color (yellow, light yellow, dark yellow, orange, light orange, dark orange). Virus-resistant plants with desirable fruit traits were hand self-pollinated to produce progeny for the next season selection. Through this pedigree selection, we developed the pumpkin in-bred line AVPU1426 (from original heterozygous and heterogeneous accession VI056782 of the WorldVeg gene bank, collected from Bangladesh) with field resistance to SLCCNV and ToLCNDV. We confirmed the resistance by screening against local isolates of SLCCNV and ToLCNDV in Thailand, and also against Squash Leaf Curl Philippines Virus (Taiwan strain) (SLCPV-TW; another important cucurbit infecting Begomovirus in SE Asia) in Taiwan. Besides assessing the yield potential and nutritional value of this line, the objective of this investigation was also to determine the mode of inheritance of resistance to SLCCNV and ToLCNDV to guide future breeding programs in C. moschata.

\section{Materials and Methods}

\subsection{Screening of Populations by Whitefly Inoculations}

The resistant line AVPU1426 was used as pollinator in a cross with the susceptible check variety Waltham Butternut to produce the $F_{1}$ generation from which the $F_{2}$ and backcross generation to the resistant parent $\left(\mathrm{BC}_{\mathrm{AVPU} 1426}\right)$ were produced. Separate screening 
for SLCCNV and ToLCNDV resistance was performed in a greenhouse using viruliferous whiteflies. Ten plants of resistant (AVPU1426) and susceptible (Waltham Butternut) parental lines and their $\mathrm{F}_{1}$, and 100 and 50 plants of the $\mathrm{F}_{2}$ and $\mathrm{BC}_{\mathrm{AVPU} 1426}$ generations (48 plants of $\mathrm{BC}_{\mathrm{AVPU} 1426}$ for SLCCNV screening), respectively, (Tables 1 and 2) were sown into the greenhouse and used in each inoculation assay. SLCCNV and ToLCNDV were maintained on pumpkin and cucumber plants in separate muslin-covered cages, respectively. Nonviruliferous whiteflies were maintained on healthy cotton (Gossypium hirsutum) grown in muslin-covered cages. Whiteflies were reared on cotton plants for at least 25-30 days to complete their life cycle and to obtain enough adult whiteflies for the transmission experiments. Whitefly transmission was performed by standard procedure [8].

Table 1. Segregation of SLCCNV resistance in $\mathrm{F}_{1}, \mathrm{~F}_{2}$, and $\mathrm{BC}$ generations derived from the cross between AVPU1426 (resistant) and Waltham Butternut (susceptible) lines of Cucurbita moschata.

\begin{tabular}{ccccccc}
\hline $\begin{array}{c}\text { Parent or } \\
\text { Generation }\end{array}$ & $\begin{array}{c}\text { Total No. } \\
\text { of Plants }\end{array}$ & $\begin{array}{c}\text { Resistant }_{\text {Plants }^{\mathbf{a}}} \\
\text { Waltham }\end{array}$ & $\begin{array}{c}\text { Susceptible } \\
\text { Plants }^{\text {a }}\end{array}$ & $\begin{array}{c}\text { Expected Segregation for Single } \\
\text { Recessive Resistance Gene (R:S) }\end{array}$ & $\mathrm{X}^{\mathbf{2}}$ & $\boldsymbol{p}_{\text {-Value }}$ \\
Butternut & 10 & 0 & 10 & $0: 1$ & - & - \\
AVPU1426 & 10 & 10 & 0 & $1: 0$ & - & - \\
$\mathrm{F}_{1}$ & 10 & 0 & 10 & $0: 1$ & - \\
$\mathrm{F}_{2}$ & 100 & 24 & 76 & $1: 3$ & 0.053 & 0.817 \\
$\mathrm{BC}_{\mathrm{AVPU} 1426}$ & 48 & 18 & 30 & $1: 1$ & 2.96 & 0.083 \\
\hline
\end{tabular}

a Plants scoring 0 and 1 on the basis of their symptoms were classified as showing resistance, whereas plants scoring 2 to 4 were classified as susceptible. $\mathrm{X}^{2}$ at 0.05 with $1 \mathrm{df}=3.84$.

Table 2. Segregation of ToLCNDV resistance in $\mathrm{F}_{1}, \mathrm{~F}_{2}$, and $\mathrm{BC}$ generations derived from the cross between AVPU1426 (resistant) and Waltham Butternut (susceptible) lines of Cucurbita moschata.

\begin{tabular}{|c|c|c|c|c|c|c|}
\hline Parent or Cross & $\begin{array}{l}\text { No. of } \\
\text { Plants }\end{array}$ & $\begin{array}{l}\text { Resistant } \\
\text { Plants }\end{array}$ & $\begin{array}{l}\text { Susceptible } \\
\text { Plants }\end{array}$ & $\begin{array}{l}\text { Expected Segregation for Single } \\
\text { Recessive Resistance Gene (R:S) }\end{array}$ & $\mathrm{X}^{2}$ & $p$-Value \\
\hline $\begin{array}{l}\text { Waltham } \\
\text { Butternut }\end{array}$ & 10 & 0 & 10 & $0: 1$ & - & - \\
\hline AVPU1426 & 10 & 10 & 0 & $1: 0$ & - & - \\
\hline $\mathrm{F}_{1}$ & 10 & 0 & 10 & $0: 1$ & - & - \\
\hline $\mathrm{F}_{2}$ & 100 & 27 & 73 & $1: 3$ & 0.213 & 0.644 \\
\hline $\mathrm{BC}_{\text {AVPU1426 }}$ & 50 & 23 & 27 & $1: 1$ & 0.32 & 0.571 \\
\hline
\end{tabular}

a Plants scoring 0 and 1 on the basis of their symptoms were classified as showing resistance, whereas plants scoring 2 to 4 were classified as susceptible. $X^{2}$ at 0.05 with $1 \mathrm{df}=3.84$.

Non-viruliferous whiteflies were fed separately on SLCCNV- and ToLCNDV- infected pumpkin plants for a $48 \mathrm{~h}$ acquisition period. Then, viruliferous whiteflies were transferred to feed on 12 days old pumpkin seedlings of all the assayed generations for $48 \mathrm{~h}$. After transmission, whiteflies were killed using Amitraz (Q-FAC Co., Ltd., Phraek Sa, Mueang Samut Prakan, Thailand) and Starkle G (Sotus International Co., Ltd., Pak Kret, Nonthaburi, Thailand). Inoculated pumpkin seedlings were transplanted to $45 \mathrm{~cm}$ pots and kept in the greenhouse. Evaluation of SLCCNV and ToLCNDV symptoms in each plant was conducted 35 days after inoculation (dai). Symptoms were scored using the following scale: $0=$ no visible symptom; $1=$ very mild symptom with slightly yellow mottle; $2=$ moderate symptom with yellow mottling and crinkling of leaf; $3=$ severe symptom with widespread yellow mottling to the apical shoot, leaf curling; 4 = very severe symptom with stunting of plant and leaf yellowing, curling and reduction of leaf lamina or dead plants (Figure 1) [9]. Plants with scores $0-1$ were considered resistant. Segregation ratios were compared to the expected ratios with the Chi-square test $\left(\chi^{2}\right)$. To test the presence of SLCCNV and ToLCNDV in all the plants of parental lines, F1 and segregating populations, DNA was isolated from the collected samples and subjected to PCR amplification using SLCCNV specific primers Beg434F (GAACTATGKCGAAGCGWCCAG; $\mathrm{K}=\mathrm{T}$ or $\mathrm{G}, \mathrm{W}=\mathrm{A}$ or $\mathrm{T}$ ) 
and SLC1314R (GTCAAGGTGCAGGTAATGTTC) and ToLCNDV-specific primer pairs Beg434F (GAACTATGKCGAAGCGWCCAG; K = T or G, W = A or T) and ToL1524R (AAGAGCATTCGCAGGAGGCGAG).

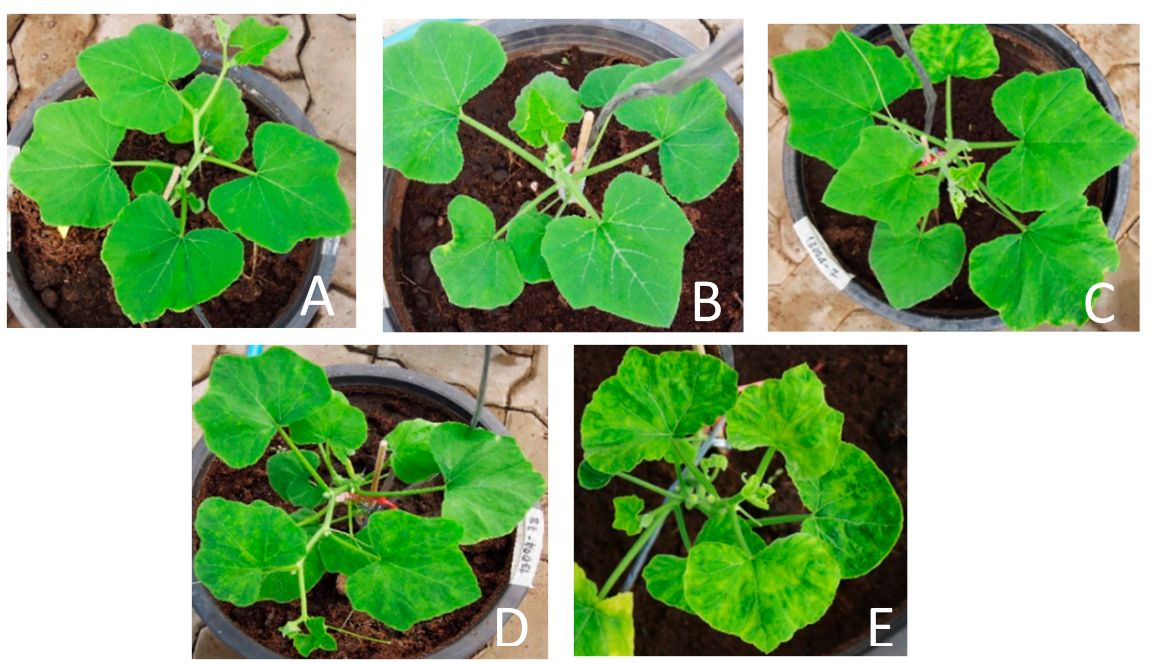

Figure 1. Symptom scoring of SLCCNV/ToLCNDV in pumpkin plants was performed according to the following scale: 0 no visible symptoms (A); 1 mild symptoms (B); 2 moderate symptoms (C); 3 severe symptoms $(\mathbf{D})$ and very severe symptoms $(\mathrm{E})$.

\subsection{Screening for Reaction to SLCPV-TW Inoculation in Taiwan}

As the parental lines and segregating populations were being screened in Thailand against SLCCNV and ToLCNDV; AVPU1426, Waltham Butternut, "Farmer's pumpkin" (SLCPV-TW susceptible checks), Nigerian local (a common source of resistance to potyviruses, with reported resistance to ToLCNDV [10], and TOT6252 (an accession of C. moschata collected in Bangladesh and previously identified as carrying some resistance to SLCPV-TW; data not shown) were screened for reaction to SLCPV-TW using viruliferous B. tabaci (B-biotype) in a net-house at WorldVeg headquarters in Shanhua, Taiwan. The trial was a completely randomized block design with three replicates of 10 seedlings each of each C. moschata line grown separately in $10 \mathrm{~cm}$ pots of sterile potting mixture. The seedlings starting at the first true leaf stage were exposed for two weeks in a net-house containing SLCPV-TW infected local susceptible "Farmer's pumpkin" plants and a high population of viruliferous whiteflies. All the plants were disturbed at least once a day to encourage the whiteflies to move between plants. Two weeks after exposure, all the plants were scored for leaf curl symptoms against a similar 0-4 scale as described above where score " 0 " = no symptoms and score " 4 " = the most severe symptoms observed on the susceptible control (Figure 1). After symptom scoring leaf tissue samples were collected from the youngest leaf of each plant that presented no symptoms (DS $=0$ ) and a few from plants showing severe symptoms and tested for the presence of SLCPV-TW DNA-A component by PCR using specific primers PKSP1 (ACGTTGTCCATACATCAATCGTC) and PKSP3R (CTCCGATTCATTTCTGCTGA) designed against conserved regions of the $A C 3$ replication enhancer protein (REn) gene and the AC1 replication-associated protein (Rep) gene, respectively.

To assess the genetic relationship between different cucurbit-infecting begomoviruses, full-length Begomovirus DNA-A sequences that had been obtained from infected cucurbit plants were retrieved from the NCBI Nucleotide database (https: / / www.ncbi.nlm.nih.gov / accessed 30 April 2021) and their pair-wise nucleotide sequence identities were compared using the Sequence Demarcation Tool (SDT) [11]. 


\subsection{Yield Trial, Fruit Traits Evaluation}

A yield trial of AVPU1426 alongside the commercial $F_{1}$ hybrid 'Rajah' and two other pumpkin lines was performed at the WorldVeg Research and Training Station, Kamphaeng Saen, Thailand. The experiment was a randomized complete block design (RCBD) with three replications. Row spacing was $5 \mathrm{~m}$, within row spacing was $1 \mathrm{~m}$, with ten transplants per plot. Seedlings were transplanted to the field on 15 November 2019 when virus incidence is at its least, and the standard local practice of regular spraying with insecticides was used to control aphid and whitefly vectors and keep virus incidence below the damage threshold. Fruits were harvested at a mature and marketable stage. Ten matured marketable fruits of each entry were assessed for average fruit weight, total soluble solids, fruit skin color, fruit shape, and fruit flesh color. Total soluble solids (TSS) expressed as degree of Brix $\left({ }^{\circ} \mathrm{B}\right)$ in fruit juice were determined using a hand refractometer.

\subsection{Carotenoids Estimation}

Eight fruits from eight randomly selected plants were taken from the harvest rows of each plot of three replications of AVPU1426. Fruits were washed with water. Seeds and the fruit skin were removed. Flesh of these eight fruit samples was cut into small pieces of approximately $3 \mathrm{~cm} \times 1.5 \mathrm{~cm}$. A sample of about $2 \mathrm{~kg}$ was placed in a $-20^{\circ} \mathrm{C}$ freezer for $8 \mathrm{~h}$ and then subjected to freeze-drying in a vacuum dryer (VirTis, Gardiner, NY, USA) for $72 \mathrm{~h}$. Extraction of the freeze-dried pumpkin powder was performed as described previously [12] with some modifications. Freeze-dried sample powder $(1.02 \pm 0.01 \mathrm{~g})$ was extracted with $20 \mathrm{~mL}$ ethanol/hexane $(4: 3 v / v)$. The samples were sonicated in an ultrasonic bath (575TAE, Advance Ceramics Technology (M) Sdn. Bh.d., Pulau Pinang, Malaysia) for 60 min (Biofuge Stratos, Thermo Electron LED GmbH, Langenselbold, Germany). For saponification, $500 \mu \mathrm{L}, 10 \%(w / v)$ potassium hydroxide in methanol:water $(4: 1, v / v)$ solution and about $200 \mathrm{mg}$ butylated hydroxytoluene was slowly added to $5 \mathrm{~mL}$ of extract supernatant under Argon (Ar) flush. The mixture was vortexed. The reaction was allowed to take place for $45 \mathrm{~min}$ at $75^{\circ} \mathrm{C}$, during which the mixture was shaken periodically.

The solution was cooled to room temperature with an ice-water bath to stop the reaction. Five $\mathrm{mL} 2 \%(w / v)$ potassium chloride and $5 \mathrm{~mL}$ n-hexane/ethyl acetate (9:1, $v / v$ ) was then added for extraction. The sample was centrifuged at $3000 \mathrm{~g}, 4{ }^{\circ} \mathrm{C}$ for $5 \mathrm{~min}$ (Biofuge Stratos, Thermo Electron LED GmbH, Germany). The upper solution phase was collected. The extraction was repeated two more times. All supernatant solutions were evaporated at $50{ }^{\circ} \mathrm{C}, 250 \mathrm{rpm}, 72 \mathrm{mbar}$ by a parallel evaporator (Syncore V-700, BUCHI Labortecnik, F AG, Flawit, Switzerland) until dryness. The dried residue was dissolved in $4.85 \mathrm{~mL} \mathrm{10 \%} \mathrm{propanol/hexane}(v / v)$, under Ar flush with vortex.

The HPLC system (Walters Alliance 2695 separation module, Waters Crop., Milford, MA, USA) equipped with a diode array detector (Model 2998, Waters Corp., Milford, MA, USA) was used. The samples were analyzed using an Xbidge ${ }^{\circledR}$ HILIC column $(3.5 \mu \mathrm{m}$, $2.1 \times 100 \mathrm{~mm}$ column Waters, Ireland). The mobile phase consisted of solvent A (95\% hexane $+0.1 \%$ formic acid) and solvent B ( $5 \%$ propanol $+0.1 \%$ formic acid) with the ratio of 95:5 $(v / v)$. The isocratic condition was used with a flow rate of $0.2 \mathrm{~mL} / \mathrm{min}$. The sample volume of $10 \mu \mathrm{L}$ was injected into the system with an autosampler and the wavelength set for detection was between $190 \mathrm{~nm}$ to $800 \mathrm{~nm}$. The chromatographic run time was $12 \mathrm{~min}$. A calibration curve of $\beta$-carotene, lutein, and zeaxanthine derived from external standard solutions in the concentration range of $1-100 \mu \mathrm{g} / \mathrm{mL}^{-1}$ was set up. The peak area of the visible chromato-gram was used to calculate the concentration of each target peak according to the equation of the standard curve. Concentration values were calculated and presented as milligrams for $\beta$-carotene and micrograms for lutein and Zeaxanthin per $100 \mathrm{~g}$ of fresh weight of pumpkin fruit (Table 3). All solvents and chemicals for the extraction were HPLC and analytical grade purchased from Sigma 9Sogma-Aldrich, St. Louis, MO, USA) and RCI Labscan, Pathumwan, Bangkok, Thailand). 
Table 3. Fruit yield, fruit weight, fruit characteristics, and carotenoid content of SLCCNV, SLCPV-TW, and ToLCNDV resistant pumpkin line AVPU1426.

\begin{tabular}{|c|c|c|c|c|c|c|c|c|c|}
\hline Entry & $\begin{array}{l}\text { Fruit Weight } \\
\text { (kg/Fruit }^{-1)}\end{array}$ & $\begin{array}{c}\text { Fruit Yield } \\
\left(\mathrm{t} / \mathrm{ha}^{-1}\right)\end{array}$ & $\begin{array}{l}\text { TSS } \\
\left({ }^{\circ} \mathrm{B}\right)\end{array}$ & $\begin{array}{l}\text { Fruit Skin } \\
\text { Color }\end{array}$ & $\begin{array}{l}\text { Fruit Flesh } \\
\text { Color }^{b}\end{array}$ & Fruit Shape & $\begin{array}{c}\beta \text {-Carotene }{ }^{\mathrm{a}} \\
(\mathrm{mg} / \mathbf{1 0 0} \mathrm{g})\end{array}$ & $\begin{array}{l}\text { Lutein }{ }^{\mathrm{a}} \\
(\mu \mathrm{g} / 100 \mathrm{~g})\end{array}$ & $\begin{array}{c}\text { Zeaxanthin a } \\
(\mu \mathrm{g} / 100 \mathrm{~g})\end{array}$ \\
\hline AVPU1426 & 3.19 & 20.74 & 6.69 & $\begin{array}{l}\text { Mottled } \\
\text { green }\end{array}$ & $\begin{array}{l}\text { Yellow- } \\
\text { orange } \\
\text { (YO16A) }\end{array}$ & Flat round & $1.57 \pm 0.26$ & $407.25 \pm 36.38$ & $429.18 \pm 15.94$ \\
\hline Rajah & 3.21 & 18.61 & 8.29 & $\begin{array}{l}\text { Mottled } \\
\text { green }\end{array}$ & $\begin{array}{l}\text { Yellow- } \\
\text { orange } \\
\text { (YO17A) }\end{array}$ & Flat round & & & \\
\hline LSD (0.05) & 0.2 & 3.86 & 1.71 & & & & & & \\
\hline
\end{tabular}

${ }^{\mathrm{a}}$ Fresh weight basis; mean \pm standard error; ${ }^{\mathrm{b}}$ Royal Horticultural Society Color Chart.

All analytical standards were standard grade purchased from Sigma (Sigma-Aldrich, St. Louis, MO, USA). Deionized water was purified using the Milli-Q-water system (Thermo Fisher Scientific, Lund, Sweden).

\section{Results}

3.1. Segregation of SLCCNV and ToLCNDV Resistances in Crosses Waltham Butternut $\times$ AVPU1426

All the plants of the Waltham Butternut showed severe symptoms (score 4; stunted plant growth with leaf yellowing, curling and reduction of leaf lamina) at 35 dai. However, plants of AVPU1426 showed no symptoms of ToLCNDV (score 0) and very mild symptoms of SLCCNV (score 1) at 35 dai, and the line was classified as resistant to both the begomoviruses (Tables 1 and 2). All the $10 \mathrm{~F} 1$ plants displayed the same susceptible phenotype (score 4) as that of the 10 susceptible-parent plants (Tables 1 and 2), indicating complete dominance of susceptibility over resistance for both viruses. The F2 progeny segregated in accordance with a 1:3 ratio of resistant to susceptible $\left(X^{2}=0.053, p=0.817\right.$ for SLCCNV; $\mathrm{X}^{2}=0.213, p=0.644$ for ToLCNDV), and the backcross to plants of the resistant parent AVPU1426 segregated in accordance with a 1:1 ratio of resistant to susceptible $\left(\mathrm{X}^{2}=2.960, p=0.083\right.$ for SLCCNV; $\mathrm{X}^{2}=0.320, p=0.571$ for ToLCNDV $)$, as would be expected if a single recessive gene from AVPU1426 conferred resistance to both the viruses (Tables 1 and 2). The positive PCR test in the resistant plants of all the generations indicates that the genotypes were exhibiting a resistance mechanism and this resistance was not attributed to any kind of escape or non-preference by the whiteflies during the screening. Thus, the resistance, although genetic, is not based on a hypersensitive immunity but more likely through action that both slow virus replication and/or virus movement and restricts symptom development [13].

\subsection{Screening for Reaction to SLCPV-TW Inoculation in Taiwan}

In the screening for reaction to SLCPV-TW in Taiwan, the Waltham Butternut and "Farmer's pumpkin" returned uniformly high disease severity (DS) scores of 3 or above (Figure 2), confirming that both were completely susceptible to SLCPV-TW. On the other hand, the plants of Nigerian local returned DS scores in the range from 0 to 3 with mean DS $=1.9$ suggesting this is an unpurified landrace still segregating for resistance and probably other traits. The plants of the inbred line AVPU1426 returned DS scores of 0 or 1 (mean $=0.53$ ), while the accession from Bangladesh (TOT 6252) also presented DS scores of 0 or 1 (mean $=0.17$ ), indicating that both lines carry good resistance to SLCPV-TW (Figure 2). Consistently, DNA-A of SLCPV-TW could be detected in the youngest leaf of all of the inoculated plants by specific PCR, though the intensity of the amplicon bands viewed after gel electrophoresis was generally lower from those with no or very mild symptoms than those from susceptible control plants, confirming that none of the five lines tested was completely immune to SLCPV-TW and that SLCPV-TW had multiplied and moved to the newest parts of the plants. 


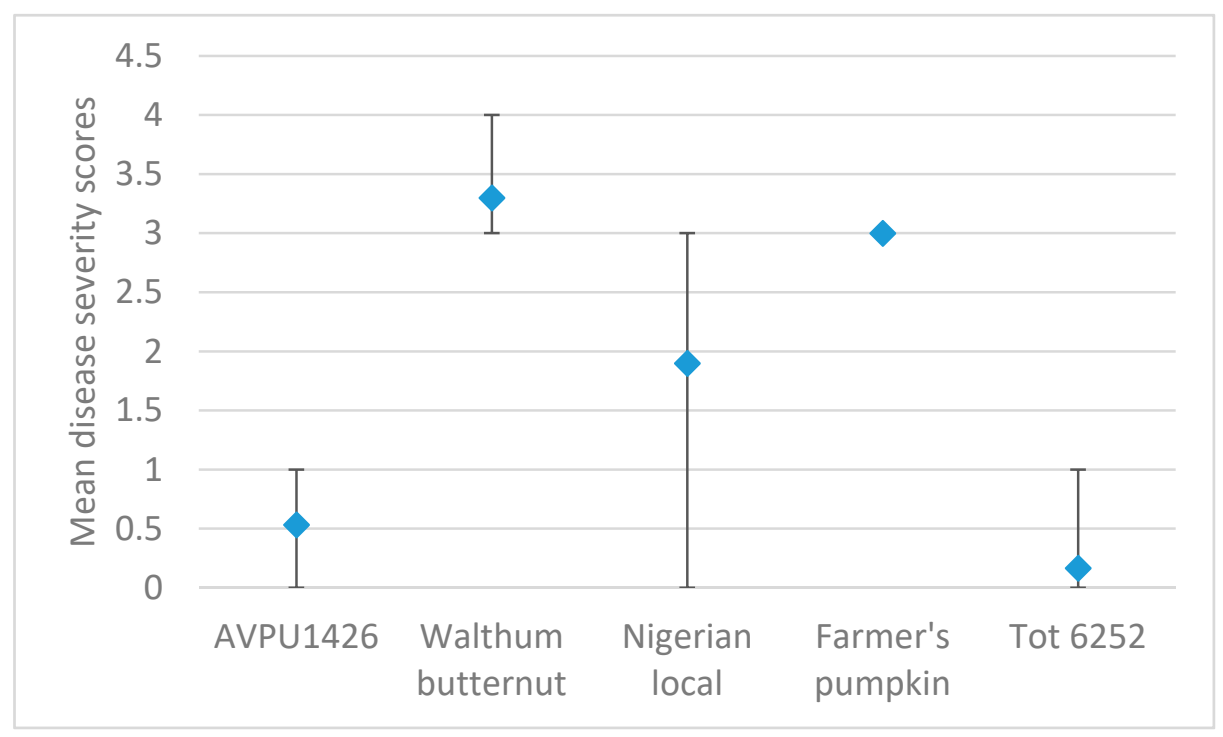

Figure 2. Comparison of disease severity scores for 30 plants each of AVPU1426 and four control varieties after challenge with SLCPV-TW for two weeks in the net-house in Taiwan (diamonds = overall mean and vertical lines represent the range between the minimum and maximum disease scored for each line).

For the cucurbit-infecting Begomovirus diversity analysis, 135 full-length DNA-A sequences of begomoviruses that have commonly been detected infecting cucurbit plants were downloaded from the NCBI nucleotide database (See Supplementary Materials Table S1) and the colored pair-wise identity (\%) matrix produced using the Sequence Demarcation Tool (SDT) is presented as Supplementary Materials Figure S1. These show that there are at least 33 distinct Begomovirus species that have been detected from cucurbit samples, and although the SLCCNV Thailand strain and the SLCPV-TW are usually regarded as distinct species, their DNA-A components show nt sequence identity greater than $94 \%$, which is greater than the species/strain threshold defined by Brown et al. [14] for Begomoviruses and so these should be regarded as strains of a single species. The nt sequence identity of the ToLCNDV Thailand strain compared to the SLCCNV, and SLCPV strains was in the range $86-91 \%$ which by the species demarcation criterion [14] confirms that ToLCNDV is a distinct, though closely related begomovirus species. Thus the three Begomoviruses used in screening in this study all fall within the SLCCNV-ToLCNDV super clade of cucurbit infecting viruses and are quite distinct in terms of nt sequence identities to the other cucurbit infecting begomoviruses.

\subsection{Horticultural, Nutritional, and Yield Potential of AVPU1426}

The fruit of AVPU1426 was flattened round, mottled green (immature stage) and mottled yellow at marketable maturity with yellow flesh (Figure 3). Fruit yield of this begomovirus-resistant open-pollinated line $\left(20.74 \mathrm{t} / \mathrm{ha}^{-1}\right)$ was comparable $(p=0.05)$ with the recently released commercial pumpkin F1 hybrid 'Rajah' $\left(18.61 \mathrm{t} / \mathrm{ha}^{-1}\right)$ of EWS. Total soluble solids (TSS) in AVPU1426 $\left(6.69^{\circ} \mathrm{B}\right)$ did not differ significantly $(p=0.05)$ from commercial cultivar 'Rajah' $\left(8.29^{\circ} \mathrm{B}\right)$. Three carotenoids, including $\beta$-carotene $(1.57 \mathrm{mg} / 100 \mathrm{~g})$, lutein $(407.25 \mu \mathrm{g} / 100 \mathrm{~g})$, and zeaxanthin $(429.18 \mu \mathrm{g} / 100 \mathrm{~g})$, were measured in the fruit of AVPU1426 (Table 3). 


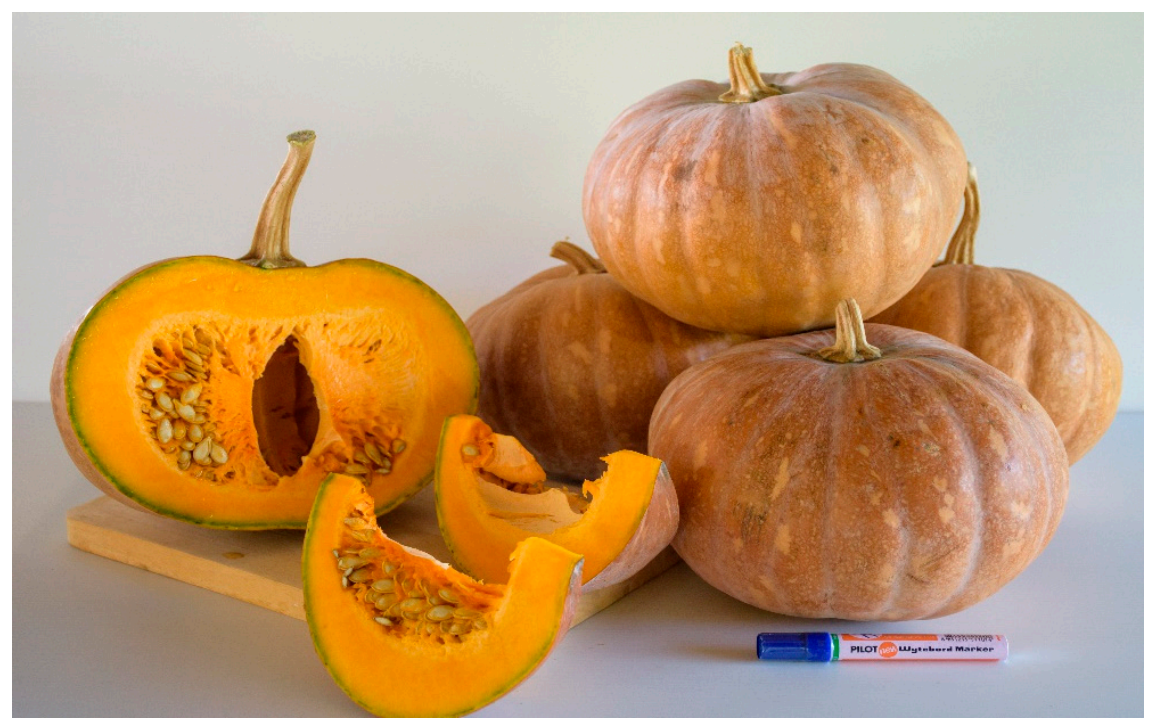

Figure 3. Fruit of SLCCNV, SLCPV-TW, and ToLCNDV resistant line AVPU1426.

\section{Discussion}

Among Cucurbita crops, C. moschata is widely cultivated by smallholder farmers in the tropics, and SLCCNV and ToLCNDV are two major production constraints resulting from viral infection in Asia, and ToLCNDV has spread in recent years to the Middle East and The Mediterranean basin to Southern Europe and North Africa [15-17]. Mixed infection of these two viruses in cucurbit fields appears at some locations in Asia [3,4]. SLCPV appears to be confined to the Philippines and Taiwan, though by the current species demarcation criterion should be regarded as a strain of SLCCNV. C. moschata is among the domesticated Cucurbita species (C. pepo L., C. maxima Duchesne, C. moschata, C. argyrosperma Huber, and C. ficifolia Bouché), the one in which more resistances to viruses have been reported [18]. Certain C. moschata accessions have been used as sources of resistance to potyviruses and cucumoviruses $[19,20]$, and commercial F1 hybrids of $C$. pepo have been developed by transferring the virus resistance genes from C. moschata [21,22].

Resistance to the New World Southern USA/Northern Mexico Begomovirus Squash Leaf Curl Virus (SLCV) was previously reported in the wild species C. ecuadorensis Cutler \& Whitaker, C. Lundelliana L.H. Bailey, C. Foetidissima Kunth, and C. okeechobeensis (Small) L.H. Bailey [23]. However, the Asian SLCCNV is quite distantly related to SLCV ( $<70 \%$ DNA-A nt sequence identity) ([24], and see Supplementary Materials Figure S1 and Supplementary Materials Table S1) and to the best of our knowledge this is the first report on a source of resistance to SLCCNV (and to SLCPV-TW) in an agronomical superior (better yield, good nutritional value, and preferred fruit market segment in South Asia,) C. moschata openpollinated line derived through pedigree selection from a Bangladeshi pumpkin land-race.

AVPU1426 is also resistant to ToLCNDV, which is relatively closely related to SLCCNV; these three viruses, as well as Tomato Leaf Curl Palampur Virus (ToLCPMV; also infects cucurbits in some areas particularly in the Middle East) fall within the SLCCNV-ToLCNDV super-clade having pair-wise DNA-A sequence identities of greater than $80 \%$. Earlier, resistance to ToLCNDV in bitter gourd, Momordica charantia L. [25] and loofah, Luffa acutangula (L.) Roxb. and L. cylindrica Roem. [26] has also been reported in Bangladeshi germplasm. Bangladesh was part of India until 1947 and ToLCNDV resistant germplasm of Luffa cylindrica [27] and melon (Cucumis melo L.) [10,28,29] has also been reported in Indian accessions.

Our study suggests that resistance to SLCCNV and ToLCNDV is controlled by a single recessive gene in AVPU1426. However, although it seems most likely, we do not know if it is the same gene conferring resistance to both of these viruses. To confirm this, we will need to perform further genotyping with separate populations segregating for resistance 
to each of the viruses. It also will be interesting to phenotype the segregating populations against SLCPV-TW, to verify if it is the same resistance acting against this strain as against the ToLCNDV.

Recently, a major recessive gene conferring resistance to ToLCNDV in C. moschata has been reported in PI 604506 and in the Indian landrace PI 381814. The resistance in PI 604506 has been mapped on chromosome 8 [30] and alleles of the same locus seem to control ToLCNDV resistance in PI 381814. It remains to be determined whether this same genomic region on chromosome 8 controls resistance to ToLCNDV in AVPU1426. It is quite likely that this region responsible for the ToLCNDV resistance is common among these different $C$. moschata accessions as the resistance to ToLCNDV in melon (Cucumis melo) is also recessive and controlled by a major locus in Chromosome 11, that maps in a region that is syntenic to that of Chromosome 8 of C. moschata [28,30]. In cucumber, monogenic recessive resistance to ToLCNDV has been recently identified, but preliminary mapping analyses show a different genomic region is implicated [29]. A single dominant gene conferring resistance to ToLCNDV also has been reported in a Japanese C. moschata accession, BSUAL-252 [31], though this is not linked to the genomic region on Chromosome 8 where the locus of the recessive gene for ToLCNDV resistance is located [31].

The multiple resistance to the studied begomoviruse (ToLCNDV, SLCCNV and SLCPV-TW) found in AVPU1426 creates the possibility of developing commercial pumpkin cultivars with increased resistance at least to the Begomovirus ToLCNDV-SLCCNV superclade. Further studies are required to map the resistance(s) and demonstrate if they are conferred by the same or different genomic loci to those reported previously, and to find linked molecular markers that facilitate marker-assisted management of the resistance(s). If new alleles/genes are found, they are promising sources for increasing the durability of resistance to begomoviruses through gene pyramiding [32]. However, although AVPU1426 was produced by multiple rounds of field screening and selection against a likely mixture of ToLCNDV and SLCCNV, and although it also shows resistance to SLCPV-TW, we do not know its reaction to more distantly related cucurbit-infecting begomoviruses such as SLCV and cucurbit leaf crumple virus in Mexico and USA, melon chlorotic mosaic and melon chlorotic leaf curl in South and Central America, telfairia mosaic virus in West Africa, or ToLCPMV and watermelon chlorotic stunt in North Africa and the Middle East. In using the resistance(s) from AVPU1426 we should also take into account that the resistance is not full immunity, but as with most of the Ty-genes for tomato leaf curl resistance in tomato, is a slowing of the virus multiplication, movement and symptom development in the plant. This means that the plants may act as a source of infection for other plants with less resistance. Also, since the begomoviruses are known to have a high mutation rate and are also able to recombine if two or more species or strains infect the same plant, we should try to reduce the selection pressure for the emergence of resistance-breaking mutant and/or recombinant strains or species.

\section{Conclusions}

A new Cucurbita moschata inbred line AVPU1426 resistant to three begomoviruses has been developed from a Bangladeshi pumpkin landrace by the World Vegetable Center through pedigree selection. Resistance to ToLCNDV and SLCCNV is governed by a recessive gene and we need to confirm whether it is the same gene conferring resistance to both of these viruses. AVPU1426 is an agronomically superior line and thus is a good candidate to breed pumpkin varieties resistant to these begomoviruses.

Supplementary Materials: The following are available online at https:/ / www.mdpi.com/article/ 10.3390/agronomy11061256/s1, Supplementary Figure S1: Colored pair-wise nucleotide sequence identity (\%) matrix (output from the SDT) for 135 full-length DNA-A sequences of begomoviruses that have been detected from cucurbit samples. Arrows point to the viruses used in screening in this study (SDT_Cucurbit_Begomoviruses_matc.png). Supplementary Table S1: Details of the NCBI GenBank accessions used with the SDT. 
Author Contributions: Conceptualization, N.P.S.D.; first draft preparation, N.P.S.D.; conducted the experiments, S.S., S.L., A.B., B.P. (Bencharong Phuangrat), N.W., R.D., Y.-L.C., K.N.J. and S.S.-t.; writing-review \& editing, N.P.S.D., O.C., K.N.J., S.S., S.-W.J., H.N., R.S., L.K., B.P. (Belén Picó) and C.S.; Funding acquisition from seed companies, N.P.S.D. All authors have read and agreed to the published version of the manuscript.

Funding: This research received external funding from Rural Development Administration (RDA PJ0127532017, PJ0127532018, PJ0127532019, PJ015548), Republic of Korea; Japan Ministry of Agriculture, Forestry and Fisheries (Japan MAFF, project no. 10000416), Spanish MICIU and FEDER AGL2017-85563-C2-1-R and Generalitat Valenciana PROMETEO project 2017/078, USAID (subaward \# 5495-KU-KSU-6056) under the project "Women in Agriculture Network (WAgN) CambodiaGender and Ecologically Sensitive Agriculture", and collaborative seed companies (World Vegetable Center project number 10000274).

Acknowledgments: Funding for this research was also provided by strategic long-term strategic donors to the World Vegetable Center: Taiwan, UK aid from the UK government, United States Agency for International Development (USAID), Australian Centre for International Agricultural Research (ACIAR), Germany, Thailand, Philippines, Republic of Korea, and Japan.

Conflicts of Interest: The authors declare no conflict of interest.

\section{References}

1. US Department of Agriculture, A.R.S. Nutrient Data Laboratory. USDA National Nutrient Database for Standard Reference, Release 28 (Slightly Revised). Version Current: May 2016. Available online: http://www.ars.usda.gov/nea/bhnrc/mafcl (accessed on 1 March 2020).

2. FAOSTAT. Available online: http:/ /www.fao.org/faostat/en/\#data/QC (accessed on 4 May 2021).

3. Nagendran, K.; Mohankumar, S.; Aravintharaj, R.; Balaji, C.G.; Manoranjitham, S.K.; Singh, A.K.; Rai, A.B.; Singh, B.; Karthikeyan, G. The occurrence and distribution of major viruses infecting cucurbits in Tamil Nadu state, India. Crop Prot. 2017, 99, 10-16. [CrossRef]

4. Chan, Y.L.; Lee, L.M.; Shih, S.L.; Kuo, F.H.; Kenyon, L. Survey of virus diseases affecting squash (Cucurbita moschata) in Taiwan. Acta. Hortic. 2019, 1257, 23-28. [CrossRef]

5. Rosen, R.; Kanakala, S.; Kliot, A.; Cathrin, P.B.; Farich, B.A.; Santana-Magal, N.; Elimelech, M.; Kontsedalov, S.; Lebedev, G.; Cilia, M.; et al. Persistent, circulative transmission of begomoviruses by whitefly vectors. Curr. Opin. Virol. 2015, 15, 1-8. [CrossRef]

6. European and Mediterranean Plant Protection Organization. EPPO Alert List-Tomato Leaf Curl New Delhi Virus. 2015. Available online: https://www.eppo.int/QUARANTINE/Alert_List/viruses/ToLCNDV.htm (accessed on 18 November 2020).

7. Rodriguez, E.; Tellez, M.M.; Janssen, D. Whitefly control strategies against tomato leaf curl New Delhi virus in greenhouse zucchini. Int. J. Environ. Res. Public Health 2019, 16, 2673. [CrossRef] [PubMed]

8. Lapidot, M.; Friedmann, M.; Pilowsky, M.; Ben-Joseph, R.; Cohen, S. Effect of host plant resistance to Tomato yellow leaf curl virus (TYLCV) on virus acquisition and transmission by its whitefly vector. Phytopathology 2001, 91, 1209-1213. [CrossRef] [PubMed]

9. Lopez, C.; Ferriol, M.; Pico, M.B. Mechanical transmission of tomato leaf curl New Delhi virus to cucurbit germplasm: Selection of tolerance sources in Cucumis melo. Euphytica 2015, 204, 679-691. [CrossRef]

10. Sáez, C.; Martínez, C.; Ferriol, M.; Manzano, S.; Velasco, L.; Jamilena, M.; López, C.; Picó, B. Resistance to Tomato leaf curl New Delhi virus in Cucurbita spp. Ann. Appl. Biol. 2016, 169, 91-105. [CrossRef]

11. Muhire, B.M.; Varsani, A.; Martin, D.P. SDT: A virus classification tool based on pairwise sequence alignment and identity calculation. PLoS ONE 2014, 9, e108277. [CrossRef] [PubMed]

12. Zhong, L.; Gustavsson, K.E.; Oredsson, S.; Glab, B.; Yilmaz, J.L.; Olsson, M.E. Determination of free and esterified carotenoid composition in rose hip fruit by HPLC-DAD-APCI+-MS. Food Chem. 2016, 210, 541-550. [CrossRef]

13. Verlaan, M.G.; Hutton, S.F.; Ibrahe, R.M.; Kormelink, R.; Visser, R.G.F.; Scott, J.W.; Edwards, J.D.; Bai, Y. The tomato yellow leaf curl virus resistance genes Ty-1 and Ty-3 are allelic and code for DFDGD-Class RNA Dependent RNA polymerases. PLoS Genet. 2013, 9, e1003399. [CrossRef]

14. Brown, J.; Zerbini, F.M.; Navas-Castillo, J.; Moriones, E.; Ramos-Sobrinho, R.; Silva, J.F.; Fiallo-Olivé, E.; Briddon, R.; HernándezZepeda, C.; Idris, A.; et al. Revision of Begomovirus taxonomy based on pairwise sequence comparisons. Arch. Virol. 2015, 160, 1593-1619. [CrossRef]

15. Juárez, M.; Tovar, R.; Fiallo-Olivé, E.; Aranda, M.A.; Gosálvez, B.; Castillo, P.; Moriones, E.; Navas-Castillo, J. First detection of tomato leaf curl New Delhi virus infecting zucchini in Spain. Plant Dis. 2014, 98, 857-858. [CrossRef]

16. Sífres, A.; Sáez, C.; Ferriol, M.; Selmani, E.A.; Riado, J.; Picó, B.; López, C. First report of tomato leaf curl New Delhi virus infecting zucchini in Morocco. Plant Dis. 2018, 102, 1045. [CrossRef]

17. Kheireddine, A.; Sifres, A.; Sáez, C.; Picó, B.; López, C. First report of tomato leaf curl New Delhi virus infecting cucurbit plants in Algeria. Plant Dis. 2019, 103, 3291. [CrossRef]

18. Martín-Hernández, A.M.; Picó, B. Natural resistances to viruses in cucurbits. Agronomy 2021, 11, 23. [CrossRef] 
19. Paris, H.S.; Cohen, S.; Burger, Y.; Yoseph, R. Single-gene resistance to Zucchini yellow mosaic virus in Cucurbita moschata. Euphytica 1988, 37, 27-29. [CrossRef]

20. Brown, R.N.; Bolanos-Herrera, A.; Myers, J.R.; Miller, J. Inheritance of resistance to four cucurbit viruses in Cucurbita moschata. Euphytica 2003, 129, 253-258. [CrossRef]

21. Paris, H.S.; Cohen, S. Oligogenic inheritance for resistance to Zucchini yellow mosaic virus in Cucurbita pepo. Ann. Appl. Biol. 2000, 136, 209-214. [CrossRef]

22. Formisano, G.; Paris, H.S.; Frusciante, L.; Ercolano, M.R. Commercial Cucurbita pepo squash hybrids carrying disease resistance introgressed from C. moschata have high genetic similarity. Plant Genet. Resour. 2010, 8, 198-203. [CrossRef]

23. McCreight, J.D.; Kishaba, A.N. Reaction of cucurbit species to squash leaf curl virus and sweetpotato whitefly. J. Am. Soc. Hortic. Sci. 1991, 116, 137-141. [CrossRef]

24. Kesumawati, E.; Okabe, S.; Khalil, M.; Alfan, G.; Bahagia, P.; Pohan, N.; Zakaria, S.; Koeda, S. Molecular Characterization of Begomoviruses Associated with Yellow Leaf Curl Disease in Solanaceae and Cucurbitaceae Crops from Northern Sumatra, Indonesia. Hortic. J. 2020, 89, 410-416. [CrossRef]

25. Yadav, K.K.; Hegde, G.; Agarwal, P.; Chawda, V.; Kenyon, L.; Dhillon, N.P.S. Multi-location preliminary field screening of World Vegetable Center bitter gourd breeding lines for reaction to Tomato leaf curl new Delhi virus in selected hotspots in India. Acta Hortic. 2019, 1257, 9-14. [CrossRef]

26. Dhillon, N.P.S.; Masud, M.A.T.; Pruangwitayakun, S.; Natheung, M.; Lertlam, S.; Jarret, R.L. Evaluation of loofah lines for resistance to tomato leaf curl New Delhi virus and downy mildew, as well as key horticultural traits. Agriculture 2020, 10, 298. [CrossRef]

27. Islam, S.; Munshi, A.D.; Mandal, B.; Kumar, R.; Behera, T.K. Genetics of resistance in Luffa cylindrica Roem against Tomato leaf curl New Delhi virus. Euphytica 2010, 174, 83-89. [CrossRef]

28. Saez, C.; Esteras, C.; Martinez, C.; Ferriol, M.; Dhillon, N.P.S.; Lopez, C.; Pico, B. Resistance to tomato leaf curl New Delhi virus in melon is controlled by a major QTL located on chromosome 11. Plant Cell Rep. 2017, 36, 1571-1584. [CrossRef]

29. Sáez, C.; Ambrosio, L.G.M.; Miguel, S.M.; Valcárcel, J.V.; Díez, M.J.; Picó, B.; López, C. Resistant sources and genetic control of resistance to ToLCNDV in cucumber. Microorganisms 2021, 9, 913. [CrossRef]

30. Saez, C.; Martinez, C.; Montero-Pau, J.; Esteras, C.; Sifres, A.; Blanca, J.; Ferriol, M.; Lopez, C.; Pico, B. A major QTL located in chromosome 8 of Cucurbita moschata is responsible for resistance to tomato leaf curl New Delhi virus. Front. Plant Sci. 2020, 11, 207. [CrossRef] [PubMed]

31. Romero-Masegosa, J.; Martinex, C.; Aguado, E.; Garcia, A.; Cebrian, G.; Iglesias-Moya, J.; Paris, H.S.; Jamilena, M. Response of Cucurbita spp. To tomato leaf curl New Delhi virus inoculation and identification of a dominant source of resistance in Cucurbita moschata. Plant Pathol. 2020, 70, 206. [CrossRef]

32. Mundt, C.C. Pyramiding for resistance durability: Theory and practice. Phytopathology 2018, 108, 79-802. [CrossRef] [PubMed] 